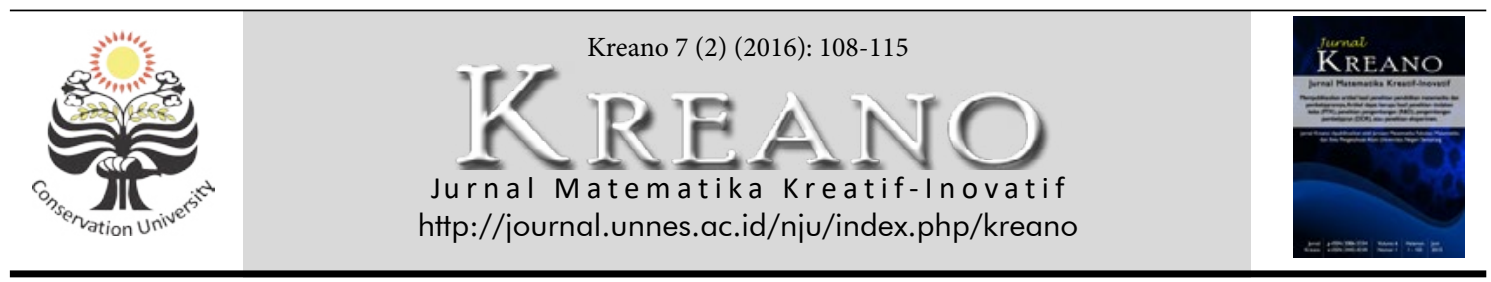

\title{
Tugas Mandiri Pre-Instructional pada Pembelajaran Kooperatif STAD untuk Meningkatkan Pemahaman Persamaan dan Garis Singgung Lingkaran
}

\author{
Nur Ali ${ }^{1}$, Abd. Qohar ${ }^{2}$ \\ 1,2Jurusan Matematika Universitas Negeri Malang \\ Email: math.alinur@gmail.com?',abd.qohar.fmipa@um.ac.id ${ }^{2}$ \\ DOI: http://dx.doi.org/10.15294/kreano.v7i2.5434
}

Received: March, 2016; Accepted: September, 2016; Published: December, 2016

\begin{abstract}
Abstrak
Tujuan penelitian ini adalah untuk mendeskripsikan langkah-langkah pemberian tugas mandiri pre-instructional pada pembelajaran kooperatif tipe STAD untuk meningkatkan pemahaman persamaan lingkaran dan garis singgung lingkaran siswa kelas XI IPA 1 SMAN g Malang. Jenis penelitian ini adalah penelitian tindakan kelas. Teknik pengumpulan data yang digunakan adalah observasi aktivitas guru dan siswa, tes tulis, catatan lapangan, dan penilaian diri siswa. Penerapan pemberian tugas mandiri pre-instructional pada pembelajaran kooperatif tipe STAD dilaksanakan dengan langkah-langkah sebagai berikut: (1) guru memberikan tugas mandiri pre-instructional sebelum pelaksanaan pembelajaran, (2) guru meninjau ulang materi sebelumnya atau prasyarat dengan strategi tanya jawab, (3) guru mengkomunikasikan tujuan dan aturan pembelajaran, (4) menerapkan pembelajaran kooperatif tipe STAD yang meliputi presentasi kelas, diskusi kelompok, dan kuis, (5) guru meminta siswa menyimpulkan materi yang dipelajari, dan (6) guru memberikan tugas mandiri pre-instructional untuk pembelajaran berikutnya. Tahap pemberian skor kemajuan individual dan penghargaan kelompok di laksanakan setelah dua kali pelaksanaan pembelajaran. Dari hasil penelitian siklus I, siswa yang mencapai nilai lebih dari atau sama dengan 78 ada sebanyak $72,22 \%$, sedangkan pada siklus II ada sebanyak 83,33\%.
\end{abstract}

\begin{abstract}
The purpose of this study is to describe the steps giving independent pre-instructional tasks on STAD cooperative learning to improve the understanding of the equation of the circle and tangent to the circle in grade 11 IPA I SMAN 9 Malang. This type of research is a classroom action research. Data collection techniques used were observation activities of teachers and students, a written test, field notes, and student self-assessment. The implementation of the giving independent pre-instructional tasks on STAD cooperative learning carried out by steps as follows: (1) the teacher gives the task independently pre-instructional prior to the implementation of learning, (2) the teacher to review the previous material or prerequisite to the strategy frequently asked questions, (3) teachers communicate the objectives and rules of learning, (4) implementing STAD cooperative learning which include class presentations, group discussions and quizzes, (5) the teacher asks the students concluded the material being studied, and (6) the teacher gives the task independently pre-instructional for the next lesson. Phase scoring the progress of individual and group awards implemented, after twice implementation of learning. From the results of the first cycle studies, students who achieve a value greater than or equal to 78 there was as much as $72.22 \%$, while in the second cycle there is as much as $83.33 \%$.
\end{abstract}

Keywords: independent pre-instructional task, STAD, equation of a circle, tangents to the circle

\section{PENDAHULUAN}

Pemahaman pada dasarnya merupakan kemampuan yang terpenting bagi siswa untuk mempelajari semua mata pelajaran. Pada mata pelajaran matematika khususnya, pemahaman konsep menjadi kemampuan mendasaryang harus dimiliki setiap siswa setelah mengikuti pembelajaran matematika. Hal je tersebut dijelaskan Suherman, dkk (2001:254) bahwa pembelajaran matematika diharapkan berakhir dengan sebuah pemahaman yang komprehensif dan holistik tentang materi yang telah disajikan.

Pentingnya pemahaman konsep dalam mempelajari matematika juga tertulis secara jelas dalam tujuan pembelajaran matematika. 
Sebagaimana tercantum dalam Depdiknas (2006:388), tujuan pembelajaran matematika adalah memahami konsep matematika, menjelaskan keterkaitan antar konsep dan mengaplikasikan konsep atau algoritma, secara luwes, akurat, efisien, dan tepat, dalam pemecahan masalah.

Berdasarkan hasil wawancara dengan guru matematika kelas XI IPA SMA Negeri 9 Malang, hasil belajar siswa yang berupa kemampuan pemahaman konsep belum sepenuhnya tercapai, terutama pada konsep persamaan lingkaran dan garis singgung lingkaran. Berdasarkan pengalamannya dalam membelajarkan kedua konsep tersebut selama beberapa tahun, masih terdapat kusulitan-kesulitan yang dialami siswa. Siswa masih banyak salah dalam menentukan pusat dan jari-jari dari suatu lingkaran jika diberikan persamaannya, menentukan kedudukan garis terhadap lingkaran, dan menentukan persamaan garis singgung lingkaran.

Berdasarkan rekap nilai ulangan harian siswa pada kedua konsep ini belum mengindikasikan siswa memahami materi secara optimal. Banyaknya siswa yang tidak tuntas dan harus mengikuti perbaikan di setiap kelasnya ada sekitar $40 \%$. Bahkan, pada tahun ajaran sebelumnya, siswa kelas XI IPA 2 yang mengikuti remidial sebanyak $46,16 \%$.

Hasil observasi terhadap pembelajaran statistika di kelas XI IPA 1 dan XI IPA 2 menunjukkan bahwa kegiatan belajar mengajar di kedua kelas tersebut belum mengindikasikan siswa aktif belajar dan mampu memahami konsep matematika dengan baik. Dalam pembelajaran dengan strategi tanya jawab dan penugasan individual ini, sebagian besar siswa tidak mengikuti kegiatan belajar dengan baik. Hal ini tercermin dari tingkat keterlibatan siswa yang masih kurang. Bahkan, ada beberapa siswa tidak memperhatikan penjelasan guru. Mereka justru sibuk mengerjakan tugas lain yang belum diselesaikan. Selain itu, siswa jugatampak tidak mampu dalam menjawab pertanyaan pada saat guru bertanya. Siswa tampak mencari-cari jawaban atas pertanyaan guru di dalam buku catatan. Di samping itu dijumpai juga seorang siswa yang tidak mampu untuk menjelaskan maksud dari apa yang dituliskannya sendiri.
Berdasarkan wawancara dengan beberapa siswa diperoleh informasi tentang minat siswa dalam belajar matematika dan pemahaman siswa setelah pembelajaran. Siswa menyatakan bahwa mereka kurang tertarik dalam mengikuti pembelajaran karena tugas yang begitu banyak. Selanjutnya, siswa juga menyatakan bahwa mereka tidak begitu paham dengan materi yang sedang ia pelajari. Lebih tegas, mereka mengetahui macam-macam pemusatan data dan mampu menyelesaikan soal-soal yang serupa dengan contoh, namun ketika diberi permasalahan yang berbeda dengan contoh, mereka tidak tahu bagaimana memulai pengerjaannya.

Dari paparan data hasil wawancara di atas menunjukkan bahwa pembelajaran belum memberikan dampak yang optimal terhadap pemahaman siswa tentang konsep persamaan lingkaran dan garis singgung lingkaran. Sedangkan, kegiatan belajar mengajar di kelas belum sepenuhnya melibatkan siswa aktif belajar. Menurut Lom(2012), pembelajaran dengan menggunakan berbagai strategi yang mengaktifkan siswa lebih efektif daripada pembelajaran yang kurang melibatkan siswa. Oleh karena itu, diperlukan sebuah inovasi pembelajaran yang dapat mengajak siswa lebih aktif membangun pemahaman sehingga kemampuan mereka dalam memahami konsep persamaan lingkaran dan garis singgung lingkaran lebih optimal.

Salah satu cara yang dapat dilakukan adalah menerapkan model pembelajaran Student Teams Achievement Divisions (STAD). Slavin (2010:12) menjelaskan bahwa gagasan utama dalam pembelajaran STAD adalah untuk memotivasi siswa supaya dapat saling mendukung dan membantu satu sama lain dalam menguasai kemampuan yang diajarkan oleh guru. Hal tersebut sebagai akibat dari adanya unsur tujuan yang harus dicapai bersama, yaitu jika para siswa ingin mendapatkan penghargaan tim, maka mereka harus membantu teman satu timnya sehingga semua anggotanya dapat menguasai materi dengan baik.

Dalam pembelajaran STAD, siswa dibekali pengetahuan melalui presentasi yang dilakukan guru. Slavin(2010:143) menjelaskan bahwa presentasi dalam STAD berbeda 
dengan presentasi guru dalam pembelajaran behavioristik, siswa tetap diajak berpikir dalam membahas konsep. Dengan demikian, melihat tuntutan yang tidak hanya sekedar presentasi dan transfer pengetahuan, siswa dalam kegiatan ini diharapkan mampu mengikuti penjelasan guru dengan baik dan melakukan kegiatan aktif seperti bertanya, menjawab pertanyaan dan memberikan gagasan. Apabila kondisi tersebut tidak terjadi, maka presentasi kelas tidak dapat terlaksana secara efektif.

Selanjutnya, dalam pembelajaran STAD siswa harus melakukan kegiatan diskusi sesama teman satu kelompoknya. Hal ini tentu mensyaratkan siswa memiliki gambaran materi terlebih dahulu. Hal tersebut juga dijelaskan oleh Yamin (2008: 160) bahwa pembelajaran dengan berdiskusi mempersyaratkan siswa memiliki latar belakang yang cukup tentang topik yang didiskusikan. Tentu, apabila siswa tidak dalam keadaan yang cukup bekal maka kegiatan diskusi tidak dapat terlaksana secara efektif.

Berdasarkan uraian tentang pentingnya pengetahuan awal siswa untuk dapat mengikuti kegiatan presentasi kelas dan diskusi kelompok, maka pembelajaran STAD saja belum cukup untuk menyelesaikan permasalahan pada pemahaman siswa terhadap konsep lingkaran dan garis singgung lingkaran. Pembelajaran harus juga didukung dengan perlakuan tambahan sehingga kedua kegiatan dalam STAD tersebut dapat terlaksana secara efektif, yaitu siswa dapat mengikuti kegiatan presentasi kelas dengan baik dan dapat menggunakan kegiatan kelompok sebagai sarana untuk benar-benar belajar. Salah satu cara yang dipilih peneliti yaitu dengan memberikan perlakuan tambahan berupa pemberian tugas mandiri pre-instructional. Melalui tugas ini, siswa akan diarahkan untuk mempelajari gambaran konsep yang akan dipelajari di kelas secara terstruktur. Sehingga, siswa dimungkinkan memiliki pengetahuan yang bermacam-macam tentang konsep tersebut. Selain itu, siswa juga dapat mempelajari keterkaitan antar konsep yang dipelajari sebelumnya, sehingga mereka memiliki cukup bekal pengetahuan dalam mengikuti tahap presentasi guru dan diskusi kelompok.
Tujuan dari penelitian ini adalah untuk mendeskripsikan langkah-langkah pemberian Tugas Mandiri Pre-instructional pada Pembelajaran Kooperatif tipe STAD untuk Meningkatkan Pemahaman Konsep Persamaan Lingkaran dan Garis Singgung Lingkaran Siswa Kelas XI IPA 1 SMAN 9 Malang.

\section{METODE}

Jenis penelitian ini merupakan penelitian tindakan kelas (classroom education research) atau PTK. Sebagaimana dijelaskan oleh Arikunto (2010:135) PTK merupakan upaya yang diatur sedemikian rupa untuk menyempurnakan atau meningkatkan proses dan praktik pembelajaran di kelas. Adapun upaya yang diberikan dalam penelitian ini adalah pemberian tugas mandiri pre-instructional pada pembelajaran kooperatif tipe STAD, sedangkan kompetensi yang akan ditingkatkan adalah pemahaman siswa tentang konsep persamaan lingkaran dan garis singgung. Penelitian ini dilakukan secara kolaboratif dan partisipatif. Kolaborasi artinya peneliti bekerjasama dengan guru kelas XI IPA 1 SMAN 9 Malang dan satu orang pengamat. Sedangkan partisipatif artinya, peneliti berpartisipasi dalam proses pembelajaran.

Subjek dalam penelitian ini adalah siswa kelas XI IPA 1 SMA Negeri 9 Malang yang berjumlah 36 orang dengan rincian 15 lakilaki dan 21 perempuan. Siklus pelaksanaan penelitian disusun berdasarkan model yang dikemukakan oleh Kemmis \& Taggard (dalam Arikunto, 2010:131) yang terdiri atas empat tahap, yaitu: (1)plan (perencanaan), (2) act (tindakan), (3) observe (pengamatan), dan (4) reflect (refleksi). Teknik pengumpulan data yang digunakan adalah nilai tes akhir siklus siswa, hasil observasi aktivitas guru dan siswa, catatan lapangan, dan penilaian diri siswa. Data yang dianalisis meliputi data hasil validasi, data hasil observasi aktivitas guru dan siswa, data pemahaman siswa, dan data hasil penilaian diri siswa.

Pemahaman masing-masing siswa ditentukan berdasarkan hasil tes akhir siklus. Namun, sebelum dilakukan penyimpulan terhadap taraf pemahaman masing-masing siswa, maka dilakukan pemberian skor yang kemudian dilanjutkan dengan penentuan ni- 
lai tes.

Pemberian skor untuk setiap pertanyaan didasarkan pada indikator-indikator pemahaman sebagaimana tersebut pada definisi operasional. Ada tiga tahap yang harus dilakukan sehingga nilai tes akhir siklus siswa dapat ditentukan. Tahap pertama, yaitu mencari skor real pada setiap soal. Skor real yang dimaksud adalah skor yang diperoleh siswa dengan membandingkan jawaban mereka dengan rubrik penyekoran pada tabel 3.6. Sehingga, skor real siswa pada setiap soal berkisar pada rentang 0-10. Tahap kedua, yaitu mencari skor siswa pada setiap soal, yaitu skor yang diperoleh siswa pada setiap soal dengan mengkonversi skor real sesuai skor maksimal soal. Selanjutnya, tahap ketiga yaitu mencari nilai siswa dengan menjumlahkan skor tiaptiap soal.

Adapun rumus dalam menentukan skor siswa pada setiap soal dan nilai tes siswa berturut-turut adalah sebagai berikut.
$S_{i}=\frac{\text { skor real tiap soal }}{\text { skor real maksimal }(10)} \times$ Skor maksimal soal
Nilai tes akhir siklus $=\sum_{i=1}^{n} s_{i}$

dengan $S_{i}$ adalah skor siswa pada soal ke- dan adalah banyaknya soal.

Untuk keperluan mengklasifikasikan taraf pemahaman siswa, peneliti menggunakan kriteria penentuan tingkat penguasaan siswa sebagaimana ditetapkan oleh Hobri (2010: 58) yang dapat dilihat pada tabel 3.7.

Tabel 2. Klasifikasi taraf pemahaman siswa

\begin{tabular}{lc}
\hline \multicolumn{1}{c}{ Interval } & Kategori \\
\hline $90 \leq \mathrm{h} \leq 100$ & Sangat Tinggi \\
$75 \leq \mathrm{h}<90$ & Tinggi \\
$60 \leq \mathrm{h}<75$ & Sedang \\
$40 \leq \mathrm{h}<60$ & Rendah \\
$0 \leq \mathrm{h}<40$ & Sangat Rendah \\
\hline
\end{tabular}

Keterangan: adalah nilai tes akhir siklus siswa

Peningkatan pemahaman siswa ditentukan dengan memperhatikan persentase ketuntasan belajar siswa secara klasikal yang dihitung dengan menggunakan rumus

Tabel 1. Rubrik pemberian skor real per soal

\begin{tabular}{|c|c|c|c|}
\hline No & Indikator Pemahaman & Uraian & Skor \\
\hline \multirow{4}{*}{1} & \multirow{5}{*}{$\begin{array}{l}\text { Mengubah soal berbentuk } \\
\text { kata-kata atau gambar ke } \\
\text { dalam symbol }\end{array}$} & Tidak ada usaha memahami soal & 0 \\
\hline & & Salah interpretasi soal secara keseluruhan & 1 \\
\hline & & Salah interpretasi pada sebagian soal & 2 \\
\hline & & Interpretasi soal benar seluruhnya & 3 \\
\hline \multirow{6}{*}{2} & & Tidak ada usaha & 0 \\
\hline & \multirow{6}{*}{$\begin{array}{l}\text { Menentukan konsep yang } \\
\text { tepat untuk digunakan } \\
\text { dalam menyelesaikan soal }\end{array}$} & Perencanaan penyelesaian yang tidak sesuai & 1 \\
\hline & & $\begin{array}{l}\text { Sebagian prosedur benar, prosedur penyelesaian } \\
\text { tidak lengkap }\end{array}$ & 2 \\
\hline & & $\begin{array}{l}\text { Prosedur substansial benar, tetapi masih terdapat } \\
\text { kesalahan, atau }\end{array}$ & \\
\hline & & $\begin{array}{l}\text { Prosedur substansial benar, namun tidak menyer- } \\
\text { takan alasan }\end{array}$ & 3 \\
\hline & & Prosedur penyelesaian benar & 4 \\
\hline \multirow{5}{*}{3} & & Tanpa jawab, atau & \\
\hline & \multirow{4}{*}{$\begin{array}{l}\text { Menerapkan konsep dalam } \\
\text { perhitungan matematis }\end{array}$} & $\begin{array}{l}\text { Jawab salah yang diakibatkan prosedur penyelesa- } \\
\text { ian tidak sesuai }\end{array}$ & 0 \\
\hline & & $\begin{array}{l}\text { Jawab salah akibat salah interpretasi atau ketidaks- } \\
\text { empurnaan prosedur }\end{array}$ & 1 \\
\hline & & $\begin{array}{l}\text { Salah komputasi, kurang teliti, salah dalam operasi } \\
\text { aljabar }\end{array}$ & 2 \\
\hline & & Penyelesaian benar & 3 \\
\hline
\end{tabular}




$$
K B k=\frac{S_{k}}{S} \times 100 \%
$$

dengan

KBk : Persentase ketuntasan belajar klasikal

$\mathrm{S}_{\mathrm{k}}$ : Jumlah siswa yang memperoleh nilai tes akhir siklus lebih dari $(h)$ atau sama dengan SKBM, yaitu 78

$S \quad$ : Jumlah seluruh siswa

Selanjutnya, apabila persentase ketuntasan belajar klasikal siswa lebih dari atau sama dengan, maka pemahaman siswa dikatakan meningkat dan tindakan dihentikan. Akan tetapi, apabila persentase ketuntasan belajar klasikal siswa kurang dari, maka pemberian tindakan dilanjutkan pada siklus berikutnya.

\section{HASIL DAN PEMBAHASAN}

Penelitian ini dilaksanakan dalam dua siklus. Masing-masing siklus terdiri dari tiga pertemuan yaitu dua pertemuan untuk pembelajaran dan satu pertemuan untuk pelaksanaan tes akhir siklus.

\section{Siklus I}

\section{Perencanaan}

Pada tahap perencanaan, hal-hal yang dilakukan peneliti meliputi (1) memilih pokok bahasan yaitu menyusun persamaan lingkaran, menentukan kedudukan titik terhadap lingkaran, dan menentukan kedudukan garis terhadap lingkaran, (2) menyusun perangkat dan instrumen penelitian yang terdiri atas Rencana Pelaksanaan Pembelajaran(RPP), Lembar Kerja Siswa (LKS), tugas mandiri pre-instructional, soal kuis, slide presentasi, lembar observasi pertemuan, soal tes akhir siklus I, dan catatan lapangan, (3) memvalidasi perangkat pembelajaran dan instrumen penelitian, dan (4) Menyusun kelompok pembelajaran pada siklus I.

\section{Pelaksanaan Tindakan}

Pelaksanaan tindakan pada pertemuan pertama dan kedua dilaksanakan pembelajaran kooperatif tipe STAD. Materi yang didiskusikan pada pertemuan pertama adalah menentukan persamaan lingkaran, sedangkan pada pertemuan kedua adalah menentukan kedudukan titik dan garis terhadap lingkaran. Pembelajaran pada pertemuan pertama dan kedua ini dimulai dengan review berkaitan dengan materi prasyarat dan membahas tugas mandiri pre-instructional. Selanjutnya, guru melakukan presentasi kelas dalam bentuk tanya jawab dengan siswa. Berikutnya, siswa melakukan aktivitas diskusi dengan teman satu kelompoknya, menyelesaikan LKS yang diberikan oleh guru, dan kemudian mempresentasikan hasil diskusi beberapa kelompok. Setelah itu, guru memberikan kuis untuk diselesaikan oleh masing-masing siswa secara mandiri. Pembelajaran kemudian diakhiri dengan penyimpulan oleh siswa tentang materi yang sedang dipelajari dan guru memberikan tugas mandiri pre-instructional kepada masing-masing siswa berkaitan dengan materi yang akan dibahas pada pertemuan selanjutnya.

Pada pelaksanaan penelitian ini, peneliti bertindak sebagai guru dengan di dampingi oleh dua orang observer. Dua observer tersebut adalah guru matematika kelas XI IPA 1 dan mahasiswa pendidikan matematika Universitas Negeri Malang.

\section{Observasi}

Observasi yang dilakukan oleh guru kelas dan satu observer sejawat selama pembelajaran meliputi observasi aktivitas guru dan aktivitas siswa. Hasil observasi aktivitas guru dan siswa pada siklus I adalah sebagai berikut.

Tabel 3. Hasil observasi aktivitas guru pada siklus I

\begin{tabular}{cccc}
\hline $\begin{array}{c}\text { Perte- } \\
\text { muan } \\
\text { ke- }\end{array}$ & $\begin{array}{c}\text { Ob- } \\
\text { server }\end{array}$ & \multicolumn{2}{c}{$\begin{array}{c}\text { Observasi keterlaksa- } \\
\text { naan aktivitas guru }\end{array}$} \\
\cline { 3 - 4 } & & Persentase & Kategori \\
\hline I & I & $84 \%$ & Baik \\
& II & $84 \%$ & Baik \\
II & I & $89 \%$ & Baik \\
& II & $87 \%$ & Baik \\
\hline Rata- & & $86 \%$ & Baik \\
rata & & & \\
\hline
\end{tabular}


Tabel 4. Hasil observasi aktivitas siswa pada siklus I

\begin{tabular}{|c|c|c|c|}
\hline \multirow{2}{*}{$\begin{array}{l}\text { Perte- } \\
\text { muan ke- }\end{array}$} & \multirow{2}{*}{$\begin{array}{l}\text { Ob- } \\
\text { server }\end{array}$} & \multicolumn{2}{|c|}{$\begin{array}{l}\text { Observasi keterlaksa- } \\
\text { naan aktivitas siswa }\end{array}$} \\
\hline & & Persentase & Kategori \\
\hline \multirow{2}{*}{ I } & I & $80 \%$ & Baik \\
\hline & II & $87 \%$ & Baik \\
\hline \multirow{2}{*}{ II } & I & $82 \%$ & Baik \\
\hline & II & $87 \%$ & Baik \\
\hline Rata-rata & & $84 \%$ & Baik \\
\hline
\end{tabular}

Tabel 3 menunjukkan bahwa aktivitas guru selama pelaksanaan pembelajaran kooperatif tipe STAD dengan memberikan tugas mandiri pre-instructional dalam kategori "baik". Sedangkan, tabel 4 menunjukkan bahwa aktivitas siswa selama pelaksanaan pembelajaran kooperatif tipe STAD dengan memberikan tugas mandiri pre-instructional termasuk dalam kategori "baik". Selain observasi aktivitas guru dan siswa, tabel 5 dan tabel 6 berikut ini adalah hasil tes akhir siswa dan tingkat pemahaman siswa pada siklus I.

Tabel 5. Hasil tes akhir siklus I

\begin{tabular}{lcc}
\hline \multicolumn{1}{c}{ Keterangan } & Banyak siswa & Persentase \\
\hline Tuntas belajar & 26 & $72,22 \%$ \\
Tidak tuntas & 10 & $27,78 \%$ \\
belajar & & \\
\hline
\end{tabular}

Tabel 6. Tingkat pemahaman siswa pada siklus I

\begin{tabular}{lcc}
\hline $\begin{array}{c}\text { Kriteria } \\
\text { Pemahaman }\end{array}$ & $\begin{array}{c}\text { Banyak } \\
\text { Siswa }\end{array}$ & Persentase \\
\hline Sangat Tinggi & 3 & $8,33 \%$ \\
Tinggi & 25 & $69,44 \%$ \\
Sedang & 7 & $19,45 \%$ \\
Rendah & 1 & $2,78 \%$ \\
Sangat Rendah & 0 & $0 \%$ \\
\hline
\end{tabular}

\section{Siklus II}

\section{Perencanaan}

Pada tahap perencanaan, hal-hal yang dilakukan peneliti meliputi (1) memilih pokok bahasan yaitu menyusun persamaan garis singgung lingkaran, (2) menyusun perangkat dan instrumen penelitian yang terdiri atas Rencana Pelaksanaan Pembelajaran(RPP), Lembar Kerja Siswa (LKS), tugas mandiri pre-instructional, soal kuis, lembar observasi pertemuan, soal tes akhir siklus II, dan catatan lapangan, dan (3) Menyusun kelompok pembelajaran pada siklus II.

\section{Pelaksanaan Tindakan}

Pelaksanaan tindakan pada siklus II dibagi ke dalam tiga pertemuan. Pertemuan pertama dan kedua dilaksanakan pembelajaran kooperatif tipe STAD. Materi yang didiskusikan pada pertemuan pertama adalah menentukan persamaan garis singgung lingkaran melalui titik pada lingkaran, sedangkan pada pertemuan kedua adalah menentukan persamaan garis singgung lingkaran melalui titik di luar lingkaran. Pembelajaran pada pertemuan pertama dan kedua ini dimulai dengan review berkaitan dengan materi prasyarat dan membahas tugas mandiri pre-instructional. Selanjutnya, guru melakukan presentasi kelas dalam bentuk ceramah dan tanya jawab dengan siswa. Berikutnya, siswa melakukan aktivitas diskusi dengan teman satu kelompoknya, menyelesaikan LKS yang diberikan oleh guru, dan kemudian mempresentasikan hasil diskusi beberapa kelompok. Setelah itu, guru memberikan kuis untuk diselesaikan oleh masing-masing siswa secara mandiri. Pembelajaran kemudian diakhiri dengan penyimpulan oleh siswa tentang materi yang sedang dipelajari dan guru memberikan tugas mandiri pre-instructional kepada masing-masing siswa berkaitan dengan materi yang akan dibahas pada pertemuan selanjutnya.

Pada pelaksanaan penelitian ini, peneliti bertindak sebagai guru dengan di dampingi oleh dua orang observer. Dua observer tersebut adalah guru matematika kelas XI IPA 1 dan mahasiswa pendidikan matematika Universitas Negeri Malang.

\section{Observasi}

Observasi yang dilakukan oleh guru kelas dan satu observer sejawat selama pembelajaran meliputi observasi aktivitas guru dan aktivitas siswa. Hasil observasi aktivitas guru dan siswa pada siklus II adalah sebagai berikut.

Tabel 7 Hasil observasi aktivitas guru pada siklus II

\begin{tabular}{cccc}
\hline \multirow{2}{*}{$\begin{array}{c}\text { Perte- } \\
\text { muan ke- }\end{array}$} & Ob- & \multicolumn{2}{c}{$\begin{array}{c}\text { Observasi keterlaksanaan } \\
\text { server }\end{array}$} \\
\cline { 3 - 4 } & & Persentase & Kategori \\
\hline \multirow{2}{*}{ I } & I & $89 \%$ & Baik \\
& II & $91 \%$ & Sangat Baik \\
II & I & $89 \%$ & Baik \\
& II & $87 \%$ & Baik \\
\hline Rata-rata & & $89 \%$ & Baik \\
\hline
\end{tabular}


Tabel 8. Hasil observasi aktivitas siswa pada siklus II

\begin{tabular}{cccc}
\hline \multirow{2}{*}{$\begin{array}{c}\text { Perte- } \\
\text { muan ke- }\end{array}$} & \multirow{2}{*}{$\begin{array}{l}\text { Ob- } \\
\text { server }\end{array}$} & $\begin{array}{c}\text { Observasi keterlaksanaan } \\
\text { aktivitas siswa }\end{array}$ \\
\cline { 3 - 4 } & I & $87 \%$ & Persentase \\
\hline \multirow{2}{*}{ I } & II & $89 \%$ & Kategori \\
& I & $87 \%$ & Baik \\
II & II & $87 \%$ & Baik \\
& & $88 \%$ & Baik \\
\hline Rata-rata & & & Baik \\
\hline
\end{tabular}

Tabel 7 menunjukkan bahwa aktivitas guru selama pelaksanaan pembelajaran kooperatif tipe STAD dengan memberikan tugas mandiri pre-instructional dalam kategori "baik". Sedangkan, tabel 8 menunjukkan bahwa aktivitas siswa selama pelaksanaan pembelajaran kooperatif tipe STAD dengan memberikan tugas mandiri pre-instructional termasuk dalam kategori "baik". Selain observasi aktivitas guru dan siswa, tabel 9 dan tabel 10 berikut ini adalah hasil tes akhir dan tingkat pemahaman siswa pada siklus II.

Tabel 9. Hasil tes akhir siklus II

\begin{tabular}{lcc}
\hline \multicolumn{1}{c}{ Keterangan } & $\begin{array}{c}\text { Banyak } \\
\text { siswa }\end{array}$ & $\begin{array}{c}\text { Persen- } \\
\text { tase }\end{array}$ \\
\hline Tuntas belajar & 30 & $83,33 \%$ \\
Tidak tuntas belajar & 6 & $16,67 \%$ \\
\hline
\end{tabular}

Tabel 10. Tingkat pemahaman siswa pada siklus II

\begin{tabular}{lcc}
\hline $\begin{array}{c}\text { Kriteria Pema- } \\
\text { haman }\end{array}$ & $\begin{array}{c}\text { Banyak } \\
\text { Siswa }\end{array}$ & Persentase \\
\hline Sangat Tinggi & 17 & $47,22 \%$ \\
Tinggi & 15 & $41,67 \%$ \\
Sedang & 4 & $11,11 \%$ \\
Rendah & 0 & $0 \%$ \\
Sangat Rendah & 0 & $0 \%$ \\
\hline
\end{tabular}

\section{Refleksi dan Diskusi Siklus 1}

Penerapan pembelajaran yang dilakukan pada siklus I telah mencerminkan langkah-langkah pemberian tugas mandiri preinstructional pada pembelajaran kooperatif tipe STAD. Hal ini didukung oleh hasil observasi aktivitas guru dan siswa yang keduanya disimpulkan dengan kategori "baik". Penerapan pembelajaran yang dilakukan pada siklus I telah mengindikasikan pemahaman siswa baik. Hal ini didukung oleh hasil tes dimana sebagian besar siswa memiliki tingkat pema- haman dengan kategori "tinggi".

Pada siklus I, penerapan tugas mandiri preinstructional pada pembelajaran kooperatif tipe STAD belum meningkatkan pemahaman konsep siswa. Hal ini dapat dilihat dari data pada tabel 5 yang menunjukkan bahwa siswa yang tuntas belajar kurang dari $75 \%$, sehingga pada siklus I indikator keberhasilan belum tercapai. Sedangkan tabel 6 memberikan informasi bahwa sesuai hasil tes akhir siklus I pemahaman mayoritas siswa terhadap konsep persamaan lingkaran tergolong dalam kategori "tinggi". Dari hasil ini maka diperlukan adanya tindakan di siklus II.

\section{Refleksi dan Diskusi Siklus 2}

Data pada Tabel 9 menunjukkan bahwa siswa yang tuntas sebesar $83,33 \%$, sehingga pada siklus II indikator keberhasilan sudah tercapai. Sedangkan tabel 10 memberikan informasi bahwa sesuai hasil tes akhir siklus II pemahaman mayoritas siswa terhadap konsep persamaan garis singgung lingkaran tergolong dalam kategori "sangat tinggi". Sehingga, sesuai kriteria keberhasilan, maka pelaksanaan tindakan dihentikan pada siklus II.

Penerapan pembelajaran yang dilakukan pada siklus II telah mencerminkan langkah-langkah pemberian tugas mandiri preinstructional pada pembelajaran kooperatif tipe STAD. Hal ini didukung oleh hasil observasi aktivitas guru dan siswa yang keduanya disimpulkan dengan kategori "baik". Penerapan pembelajaran yang dilakukan pada siklus II telah mengindikasikan pemahaman siswa baik. Hal ini didukung oleh hasil tes dimana sebagian besar siswa memiliki tingkat pemahaman "sangat tinggi".

Pada siklus II, penerapan tugas mandiri pre-instructional pada pembelajaran kooperatif tipe STAD meningkatkan pemahaman siswa tentang konsep persamaan lingkaran dan garis singgung lingkaran. Hal ini dapat dilihat dari hasil tes bahwa siswa yang telah mencapai nilai ketuntasan minimal 78 ada sebanyak 83,33\%. Hasil penelitian ini sejalan dengan apa yang telah dikemukakan oleh Tran (2013) serta Adesoji \& Ibraheem (2009), yang menyatakan bahwa pembelajaran kooperatif type STAD dapat meningkatkan hasil pem- 
belajaran matematika siswa. Tran (2013) juga menyatakan bahwa dengan pembelajaran kooperatif, keaktifan siswa dalam pembelajaran bisa meningkat. Dalam penelitian ini, ada peningkatan keaktifan siswa dalam pembelajaran yang dapat dilihat dari tabel 4 dan tabel 8. Hal ini sejalan dengan temuan Khan \& Inamullah (2011), dimana dalam penelitiannya tidak menemukan adanya peningkatan hasil dalam penerapan pembelajaran kooperatif type STAD, namun mereka menemukan bahwa dengan dengan menggunakan STAD siswa belajar lebih aktif. Dalam pembelajaran kooperatif STAD, guru perlu membimbing agar terjadi komunikasi sosial dalam kelompok sehingga mereka bisa bekerja dengan baik. $\mathrm{Hal}$ ini sesuai dengan pendapat Amiripour $\mathrm{P}_{\text {, }}$ Mofidi SA and Shahvarani A. (2012) yang menyatakan bahwa dalam kenyataannya siswa bisa meningkat komunikasi sosialnya dalam belajar matematika. Dengan demikian pembelajaran kooperatif dalam matematika tidak hanya untuk meningkatkan kemampuan kognitif siswa saja namun juga agar keaktifan dan ketrampilan sosial siswa menjadi meningkat.

\section{SIMPULAN}

Pembelajaran dengan pemberian tugas mandiri pre-instructional pada pembelajaran kooperatif tipe STAD yang dapat meningkatkan pemahaman persamaan lingkaran dan garis singgung lingkaran siswa kelas XI IPA 1 SMA Negeri 9 Malang dilakukan dengan langkah-langkah sebagai berikut.

1. Guru memberikan tugas mandiri preinstructional sebelum pelaksanaan pembelajaran

2. Guru meninjau ulang materi prasyarat atau materi sebelumnya dengan strategi ceramah dan tanya jawab.

3. Menerapkan pembelajaran dengan mengacu pada komponen pembelajaran kooperatif tipe STAD.

4. Guru meminta siswa menyimpulkan materi yang dipelajari

5. Guru memberikan tugas mandiri pre-instructional kepada setiap siswa berkaitan dengan materi pembelajaran yang akan dibahas pada pertemuan berikutnya.

\section{SARAN}

Setelah melaksanakan penelitian, ada beberapa hal yang disarankan agar pembelajaran bisa berjalan dengan baik yaitu:

1. Dalam memberikan tugas mandiri preinstructional kepada setiap siswa, guru harus memilih materi yang merupakan prasyarat dan materi pembelajaran yang akan dibahas pada pertemuan berikutnya, agar tugas tersebut tidak menjadi beban yang berlebihan pada siswa.

2. Perlu adanya penelitian lebih lanjut tentang pemberian tugas mandiri pre-instructional kepada setiap siswa dengan menggunakan pembelajaran kooperatif selain STAD.

\section{DAFTAR PUSTAKA}

Adesoji, F. A., Ibraheem, T. L. (2009). Effects of Student Teams-Achievement Divisions Strategy And Mathematics Knowlegde On Learning Outcomes In Chemical Kinetics. The Journal of International Social Research. Vol 2 (6) Winter

Amiripour P, Mofidi SA and Shahvarani A. (2012). Scaffolding as effective method for mathematical learning. Indian Journal of Science and Technology.

Arikunto, S.(2010). Prosedur Penelitian suatu Pendekatan Praktek. Jakarta: Rineka Cipta.

Depdiknas. (2006). PanduanKurikulum Tingkat SatuanPendidikan (KTSP). Jakarta: DepartemenPendidikanNasional.

Hobri. (2010). Metodologi Penelitian Pengembangan. Jember: Pena Salsabila.

Khan, G. N.; Inamullah, H. M. (2011). Effect of Student's Team Achievement Division (STAD) on Academic Achievement of Students. Asian Social Science. Vol. 7, No. $12: 211-215$

Lom, B. (2012). Classroom Activities: Simple Strategies to Incorporate Student-Centered Activities within Undergraduate Science Lectures. The Journal of Undergraduate Neuroscience Education (JUNE), Fall 2012, 11(1):A64-A71

Suherman, dkk. 2001. Strategi Pembelajaran Matematika Kontemporer. Bandung: JICA Universitas Pendidikan Indonesia (UPI).

Slavin, Robert E. 2010. Cooperative Learning: Teori, Riset, dan Praktik. Bandung: Nusa Media.

Tran, V. D. (2013). Effects of Student Teams Achievement Division (STAD) on Academic Achievement, and Attitudes of Grade gth Secondary School Students towards Mathematics. International Journal of Sciences. Volume 2, Issue Apr 2013.

Yamin, Martinis. 2008. Desain Pembelajaran Berbasis Tingkat Satuan Pendidikan. Jakarta: Gaung Persada Press 